\title{
Carbon Dioxide Emissions and Energy Self-Sufficiency of Woody Biomass Utilization for Residential Heating: A Case Study of Nishiwaga, Japan
}

\author{
Daisuke Sawauchi1 ${ }^{*}$, Daisuke Kunii', Yasutaka Yamamoto² \\ ${ }^{1}$ Policy Research Institute, Ministry of Agriculture, Forestry, and Fisheries, Tokyo, Japan \\ ${ }^{2}$ Research Faculty of Agriculture, Hokkaido University, Sapporo, Japan \\ Email: dsawauchi@gmail.com
}

Received 10 March 2015; accepted 10 April 2015; published 13 April 2015

Copyright (C) 2015 by authors and Scientific Research Publishing Inc.

This work is licensed under the Creative Commons Attribution International License (CC BY).

http://creativecommons.org/licenses/by/4.0/

(c) (i) Open Access

\begin{abstract}
Renewable energy sources, including bioenergy, are presently attracting considerable attention as possible substitutes for fossil fuels. Among the various sources of bioenergy, biomass can arguably play a significant role in the reduction of greenhouse gases and the provision of a stable energy supply. However, the use of fossil fuels continues in the production of bioenergy. Consequently, the overall extent to which biomass utilization for energy can reduce carbon dioxide emissions as a substitute for fossil fuels and whether this can improve the energy self-sufficiency rate remains largely unknown. This study responds to these questions using a case of a Japanese rural community using firewood for residential heating. The results showed that woody biomass utilization for energy is able to both reduce the dependence on fossil fuels and mitigate climate change. These findings offer new insights into the development of sustainability in rural communities.
\end{abstract}

\section{Keywords}

Carbon Dioxide Emissions, Energy Self-Sufficiency, Woody Biomass, Bioenergy, Residential Heating, Japan

\section{Introduction}

Renewable energy sources are presently attracting considerable attention as possible substitutes for fossil fuels. ${ }^{*}$ Corresponding author.

How to cite this paper: Sawauchi, D., Kunii, D. and Yamamoto, Y. (2015) Carbon Dioxide Emissions and Energy Self-Sufficiency of Woody Biomass Utilization for Residential Heating: A Case Study of Nishiwaga, Japan. Journal of Environmental Protection, 6, 321-327. http://dx.doi.org/10.4236/jep.2015.64032 
Among these, woody biomass is obviously attractive to those rural communities with access to an abundant supply of forest resources. The utilization of woody biomass for energy offers several key benefits, including job creation, an additional income source for the forestry sector [1], mitigating global warming, and securing a stable energy supply. Moreover, using renewable biological resources for energy contributes to promoting the creation of a bioeconomy [2].

While bioenergy, including woody biomass utilization for energy generation, can play a critical role in the mitigation of climate change, there are a number of complicating issues to consider, such as the sustainability of practices and the efficiency of bioenergy systems [3]. For instance, the general assumption is that biomass utilization for energy generation is "carbon neutral" over its life cycle because the combustion of the biomass releases the same amount of carbon dioxide $\left(\mathrm{CO}_{2}\right)$ as captured by the plant during its growth [4]. However, there are also greenhouse gas (GHG) emissions arising during the production stages because external fossil fuel inputs are required to produce and harvest the biomass feedstock [4] [5]. We must then account for all energy inputs and GHG emissions occurring during the production stages from a life cycle perspective [4] [5].

Along with these measurement concerns, the indirect effects of promoting biomass utilization for energy may have a negative impact on the reduction of GHG emissions [6] [7]. It is common to use economic models to analyze these indirect effects through prices and markets. For example, Havlík et al. [6] analyzed the effects of indirect land use change caused by increasing needs for biofuel using a partial equilibrium model. Similarly, Deppermann et al. [7] developed an economic general equilibrium model to assess both the direct and indirect effects of the European Union's policies on biomass utilization for energy generation in a global context through the linkages between agricultural and energy markets.

Further, in terms of a secure energy supply, Japan is largely dependent on the import of oil, coal, and natural gas. In 2010, Japan's energy self-sufficiency rate was just 5\% [8]. In order to secure a stable supply of energy, alternatives to fossil fuel need to be developed. The expectation is that woody biomass will serve as an alternative energy source and help contribute to increasing energy self-sufficiency.

Unfortunately, the extent to which woody biomass utilization for energy can reduce $\mathrm{CO}_{2}$ emissions as substitutes for fossil fuels and how this can improve the rate of energy self-sufficiency in Japan remains unknown. This study addresses these important questions using data from a Japanese rural community that uses firewood for residential heating. This is an important area concerning the residential heating via woody biomass may not only contribute to climate change mitigation and the provision of a stable energy supply from a business perspective but may also enhance traditional rural communities in Japan. We offer a new value to Japanese rural life by visualizing its environmental impact.

Although there are some existing studies on the assessment of woody biomass utilization for energy in Japan, these tend to focus on woody biomass utilization for energy as a business [9]-[16]. They also generally analyze woody biomass utilization for energy in Japan using only biomass availability through geographical information systems (GIS) [9]-[11], the total efficiency of related business projects [12], the economic and environmental impact using input-output analysis [13], and the optimization of transportation [14]. Few focus on wood biomass utilization for residential heating [15] [16]. Further, while some of these studies calculated the reduction in GHG emissions associated with woody biomass utilization for the residential heating [15] [16], they did not assess the impact from the perspective of a stable energy supply.

\section{Methodology}

\subsection{Case Study Area}

Japan is a country with relatively abundant forest resources; forests cover approximately $68.2 \%$ of the total land area. However, with the decline in the prices of forest products and increasing management costs, Japan's forestry industry is facing severe management conditions [8]. As a result, Japan's domestic forest resources are underutilized, and some forests are now at risk of losing their ability to provide multiple environmental functions. With new markets for low-grade forest products, forest owners will be able to use a great array of management techniques to produce higher quality timber, and improve forest health [17]. Therefore, in numerous rural communities in Japan, there has been directed toward using low-grade forest products as sources of woody biomass.

The case study area is Nishiwaga in Iwate Prefecture (Figure 1). The total area of the town is $590.8 \mathrm{~km}^{2}$ with $87 \%$ covered by forests. In Nishiwaga, 617 households ( $25 \%$ of all households) use firewood stoves for residential heating [18]. Almost half of the residents who use firewood stoves in Nishiwaga procure their firewood by cutting down the trees themselves [18]. 


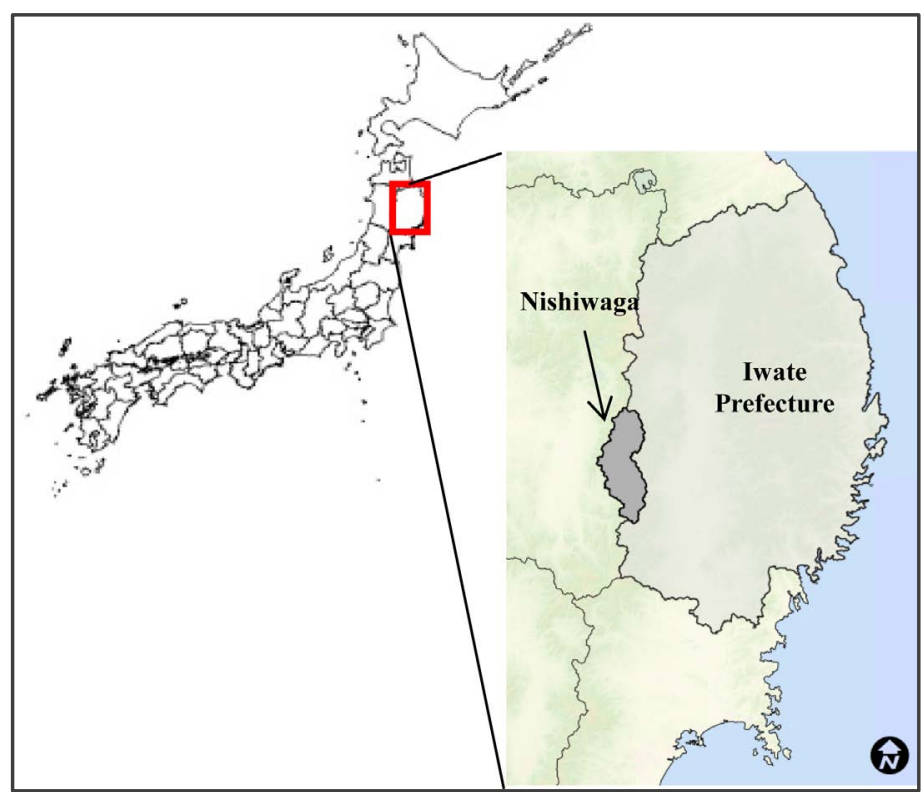

Figure 1. Location of Nishiwaga.

Kunii et al. [15] estimated the amount of technically available firewood stock in Nishiwaga using GIS and found that this was more than one hundred times the amount of firewood consumed each year in the town. This suggests that Nishiwaga has abundant forest resources and that the promotion of firewood utilization by the town's residents may not have a severe negative impact through unsustainable practice and indirect land use change.

Kunii et al. [15] also investigated the economic and environmental performance of firewood utilization in Nishiwaga. However, while they estimated the reduction in GHG emissions from the reduction of fossil fuel use, they did not consider the GHG emissions incurred during the production stages. In this study, we calculate the reduction in GHG emissions by woody biomass utilization for energy from a life cycle perspective by including the GHG emissions during the production stages. Unlike Kunii et al. [15], we also calculate the enhanced energy self-sufficiency rate arising from firewood use.

\subsection{Carbon Dioxide Emission Reductions from Firewood Utilization}

To estimate the reduction in GHG emissions, we consider two cases as explained below:

1) Baseline for comparison: kerosene, which is the main winter heating fuel in Japan, supplies the energy used for heating purposes for all households in Nishiwaga.

2) Firewood substitution: firewood instead of kerosene supplies the energy used for heating purposes for just $25 \%$ of the households in Nishiwaga.

The system boundary for firewood utilization includes tree harvesting, processing and transporting firewood, and burning firewood (Figure 2). The only GHG measured is $\mathrm{CO}_{2}$ and the functional unit is the amount of heat consumed by a household in Nishiwaga that uses firewood stoves for residential heating. On average, a household in Nishiwaga consumes $3.5 \mathrm{~m}^{3}$ of firewood for residential heating annually [18]. In this analysis, we follow Smith's et al. [3] recommendation to calculate $\mathrm{CO}_{2}$ emissions from a life cycle perspective. As the total volume of woody biomass used in the town is small relative to the volume of woody biomass distributed across Japan, we do not consider any indirect effects, such as land use change and the economic linkage between woody biomass and other sectors through prices and markets [6] [7].

We calculate the reduction in $\mathrm{CO}_{2}$ (Reduction $\left.{ }_{\text {total }}\right)$ by subtracting the $\mathrm{CO}_{2}$ emissions needed to produce firewood $\left(\right.$ Emission $_{\text {wood }}$ ) from reduction in $\mathrm{CO}_{2}$ emissions resulting from the reduction in the use of kerosene (Re-

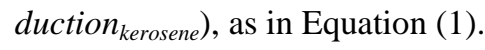

$$
\text { Reduction }_{\text {total }}=\text { Reduction }_{\text {kerosene }}-\text { Emission }_{\text {wood }}
$$

We estimate Emission $_{\text {wood }}$ using the data from the verification test results in Nishiwaga-machi [18] and the 


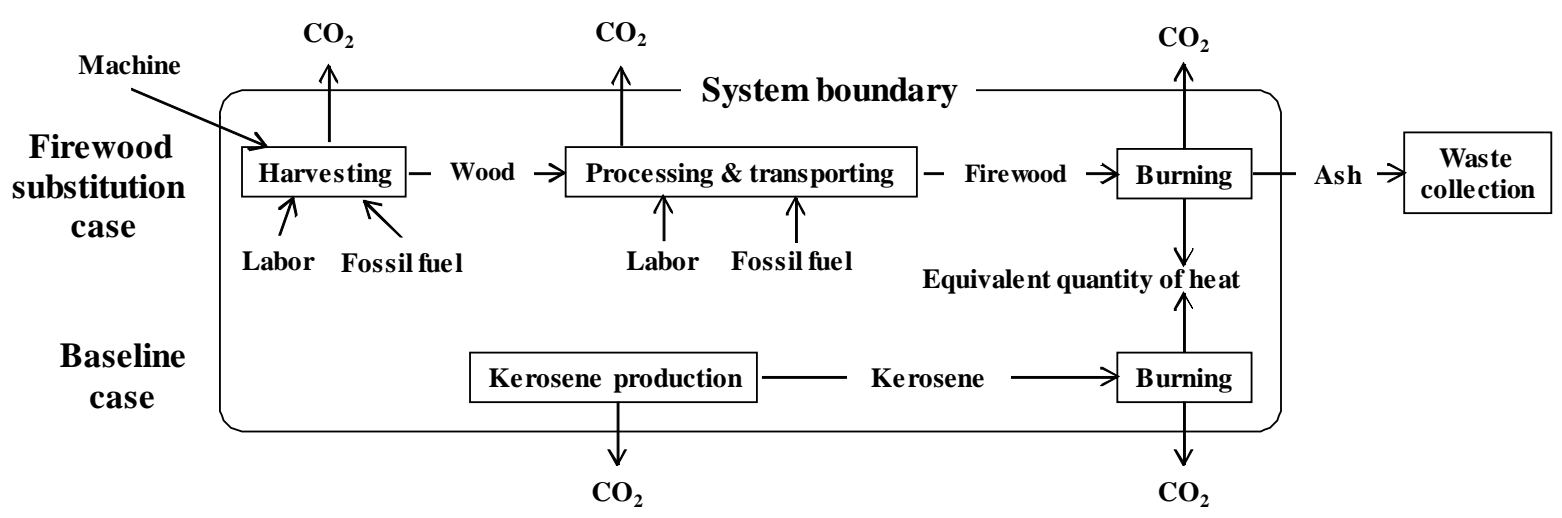

Figure 2. System boundaries.

emission factors for diesel oil and gasoline [19]. Table 1 summarizes the component amounts of diesel oil used for machinery and trucks to produce a functional unit of firewood, summing to 30.1 liters (L) of diesel oil. Among the various work processes, wood splitting requires the largest amount of diesel oil with $40 \%$ of total consumption during this process alone. The amount of gasoline used for passenger vehicles and the chainsaws used for harvesting trees to produce a functional unit of firewood is 3.2 L [18].

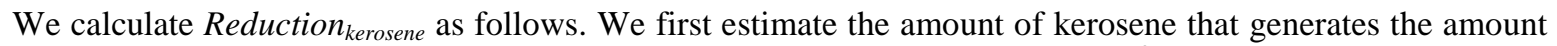
of heat equivalent to a functional unit, being the heat generated from burning $3.5 \mathrm{~m}^{3}$ of firewood, as described in Equation (2).

$$
\text { Heat }=\text { BulkDen } \times \text { UnitHeat } \times \text { Conversion } \times 3.5 \text {. }
$$

Heat is the megajoules (MJ) of heat generation per $3.5 \mathrm{~m}^{3}$ of firewood. BulkDen is bulk density, defined as the weight per $1 \mathrm{~m}^{3}$ of firewood in kilograms per $1 \mathrm{~m}^{3}\left(\mathrm{~kg} / \mathrm{m}^{3}\right)$. UnitHeat is the amount of heat generation per 1 $\mathrm{kg}$ of firewood in kilocalories per $\mathrm{kg}(\mathrm{kcal} / \mathrm{kg}$ ). We assume the type of firewood is Nara (oak) with $20 \%$ moisture content. Conversion is the conversion factor from kcal to MJ. We calculate Heat to be 35,168 MJ using 680 $\left(\mathrm{kg} / \mathrm{m}^{3}\right)$ for BulkDen, $3530(\mathrm{kcal} / \mathrm{kg})$ for UnitHeat, and 1/238.9 (MJ/kcal) for Conversion. As the heat generated from $1 \mathrm{~L}$ of kerosene is $43.38 \mathrm{MJ}$ [20], the volume of kerosene that generates an equivalent amount of heat to Heat is $812 \mathrm{~L}$.

We then multiply the following emission factors for kerosene to the amount of kerosene to calculate Reduction $n_{\text {kerosene. }}$ The amount of $\mathrm{CO}_{2}$ generated from burning $1 \mathrm{~L}$ of kerosene is $2.49 \mathrm{~kg} \mathrm{CO}_{2} / \mathrm{L}$ [21], while the $\mathrm{CO}_{2}$ generated in producing $1 \mathrm{~L}$ of kerosene is $155.8 \mathrm{~g} \mathrm{CO}_{2} / \mathrm{L}$ [19].

\subsection{Carbon Dioxide Emission Reductions from Firewood Utilization}

While Japan's energy self-sufficiency rate is currently very low, the expectation is that woody biomass utilization for energy will significantly increase the energy self-sufficiency rate as a domestic energy source. In this study, we calculate the energy self-sufficiency rate from the use of firewood in Nishiwaga (Energy self-sufficiency rate) using Equation (3).

$$
\text { Energy self }- \text { sufficiency rate }=\text { Energy }_{\text {wood }} / \text { Energy }_{\text {total }} \text {, }
$$

where Energy wood $_{\text {is }}$ the energy supplied from firewood in Nishiwaga in 2009 and calculated by multiplying Heat and the number (617) of households using firewood stoves for residential heating in Nishiwaga.

Energy $_{\text {total }}$ is total energy consumption in Nishiwaga in 2009. According to the method in the Guidelines of the Agency for Natural Resources and Energy [22], we calculate Energy total. The method in the guidelines estimates the energy consumption in a municipality by dividing the energy consumption data, published by each prefecture, and using indices such as the production volume and investment in production.

\section{Results and Discussion}

Table 2 summarizes the $\mathrm{CO}_{2}$ emissions per functional unit of firewood and kerosene. We calculate the amount 
Table 1. Amount of diesel oil used to produce a functional unit of firewood.

\begin{tabular}{ccc}
\hline Work process & Amount of diesel oil used (L) & Percentage \\
\hline Maintaining the strip road & 1.1 & $4 \%$ \\
Carrying equipment & 1.4 & $5 \%$ \\
Collecting harvested wood & 4.9 & $16 \%$ \\
Loading on truck & 6.3 & $20 \%$ \\
Removing scrub & 0.4 & $1 \%$ \\
Carrying wood from forest & 2.5 & $8 \%$ \\
Unloading from truck & 1.8 & $6 \%$ \\
Wood splitting & 12.3 & $40 \%$ \\
Total & 30.1 & $100 \%$ \\
\hline
\end{tabular}

Source: Calculated by the authors based on Nishiwaga-machi [18].

Table 2. Comparison of the amount of $\mathrm{CO}_{2}$ emissions from a functional unit of firewood and kerosene.

\begin{tabular}{ccc}
\hline Item & $3.5 \mathrm{~m}^{3}$ of firewood & 812 $\mathrm{L}$ of kerosene \\
\hline Amount of heat $(\mathrm{MJ})$ & & 35,168 \\
Total amount of discharged $\mathrm{CO}_{2}\left(\mathrm{~kg} \mathrm{CO}_{2}\right)$ & 86.5 & 2146.6 \\
Burnt at home $\left(\mathrm{kg} \mathrm{CO}_{2}\right)$ & 0.0 & 2020.2 \\
During production $\left(\mathrm{kg} \mathrm{CO}_{2}\right)$ & 86.5 & 126.4 \\
\hline
\end{tabular}

Note: The amount of $\mathrm{CO}_{2}$ generated during firewood burning is zero because it is carbon neutral.

of $\mathrm{CO}_{2}$ emissions arising from the use of diesel oil and gasoline during the production of a functional unit of firewood at $86.5 \mathrm{~kg} \mathrm{CO}_{2}$. Firewood is biomass, and because the amount of $\mathrm{CO}_{2}$ emitted during burning counts as zero, the amount of $\mathrm{CO}_{2}$ emitted is $86.5 \mathrm{~kg} \mathrm{CO}$.

By using a functional unit of firewood in Nishiwaga, a reduction in $\mathrm{CO}_{2}$ emissions of $2060.1 \mathrm{~kg} \mathrm{CO}_{2}(=$ 2146.6 - 86.5) is expected. The $\mathrm{CO}_{2}$ reduction rate is then $96 \%(=2060.1 / 2146.6)$. The use of firewood by the 617 households can then reduce the amount of kerosene by 500 kiloliters $(\mathrm{kL})$ and $\mathrm{CO}_{2}$ emissions by some 1271 $\mathrm{t} \mathrm{CO}_{2}$. Note that while the magnitude of the $\mathrm{CO}_{2}$ reduction is small in a global context given the small scale, woody biomass as an alternative energy source for residential heating has a relatively high reduction rate in $\mathrm{CO}_{2}$.

In terms of comparable results, Kunii et al. [15] estimated that $\mathrm{CO}_{2}$ emissions per household fell by $1.9 \mathrm{t} \mathrm{CO}_{2}$ when replacing the use of kerosene with firewood in Nishiwaga. The slight difference in results arises from differences in the following assumptions. First, the way we calculate $\mathrm{CO}_{2}$ emissions is different. While Kunii et al. [15] did not include the energy inputs and $\mathrm{CO}_{2}$ emissions needed to produce the firewood, we consider all energy inputs and GHG emissions in the production stages from a life cycle perspective. Second, the tree species used for the firewood and its calorific value differ. Kunii et al. [15] assumed Japanese cedar as the firewood tree species because it accounts for about one-third of the forest area in Nishiwaga and the effective utilization of the residue of harvested Japanese cedar would be ideal. However, we assumed oak as the firewood tree species because it is the most common species used for firewood in Nishiwaga. Despite these differences in assumptions, our results support those in Kunii et al. [15].

In Table 3, we list the amount of energy for each sector in Nishiwaga. In one year, the total energy used in the town $\left(\right.$ Energy $_{\text {total }}$ ) is 430 terajoules (TJ), where the residential sector consumes $124 \mathrm{TJ}$, including the energy used for residential heating, $270 \mathrm{TJ}$ is from petroleum products, and $160 \mathrm{TJ}$ is from electric power.

We calculate the energy from firewood used by the households in Nishiwaga (Energy wood $_{\text {) }}$ as 21.7 TJ. The energy self-sufficiency arising from the use of firewood in Nishiwaga (Energy self-sufficiency rate) described by Equation (3) is then $5 \%$. This corresponds to $23 \%$ of the energy used by the households in the town. These results suggest that woody biomass utilization makes it possible to both improve the energy self-sufficiency rate and contribute to the securing of the energy supply, especially in the residential sector. 
Table 3. Amount of diesel oil used to produce a functional unit of firewood.

\begin{tabular}{cccc}
\hline \multirow{2}{*}{ Energy consumption sector } & \multicolumn{1}{c}{ Energy Source } & Total \\
\cline { 2 - 4 } Manufacturing industry & Petroleum products & Electric power & 39 \\
Nonmanufacturing industry & 9 & 30 & 105 \\
Residential and commercial & 91 & 14 & 236 \\
(Residential) & 120 & 116 & $(124)$ \\
(Commercial and others) & $(75)$ & $(49)$ & $(113)$ \\
Transportation (passengers vehicles) & $(45)$ & 0 & 50 \\
Total & 50 & 160 & 430 \\
\hline
\end{tabular}

Source: Authors’ calculations. Note: Table does not include coal, coal products, town gas and heat given zero energy consumption.

\section{Conclusions}

Renewable energy sources such as biomass are presently attracting considerable attention as possible substitutes for fossil fuels. Among these, bioenergy can play a significant role in GHG reduction and the securing of a stable energy supply as an alternative energy source to fossil fuel. However, the production of biomass energy also requires the use of fossil fuels. Hence, the extent to which woody biomass utilization for energy can reduce $\mathrm{CO}_{2}$ emissions as substitutes for fossil fuels and how this can improve the energy self-sufficiency rate remains unknown.

This study clarified the reduction in $\mathrm{CO}_{2}$ emissions and the effect on the energy self-sufficiency rate from the utilization of woody biomass for energy in households. The results showed that the use of firewood for residential heating reduced the amount of kerosene and yielded a significantly high reduction rate in $\mathrm{CO}_{2}$ emissions, even when all energy inputs and GHG emissions incurred during the production stages were accounted for using a life cycle perspective. This study also showed that the energy generated from firewood accounted for $5 \%$ of the total energy consumption in the town and $23 \%$ of the energy consumed by the household sector. These results suggested that promoting the woody biomass utilization for residential heating might reduce the amount of $\mathrm{CO}_{2}$ emissions from households and improve energy self-sufficiency. The results also offer new values for rural life.

In terms of study limitations, we restricted ourselves to a single case and did not consider GHGs other than $\mathrm{CO}_{2}$. Some previous studies have pointed out that expansion of biomass utilization for energy at the global level may have a negative impact on the environment through prices and markets. As the study area represents only a small part of Japan, we assumed away indirect impacts in our analysis. We intend to reexamine this assumption in future research.

\section{Acknowledgements}

This research was supported in part by Japan Society for the Promotion of Science KAKENHI Grant No. 25660175. Our work benefited from discussions with experts at the New Zealand Life Cycle Assessment Conference 2014, held during 2-3 September 2014, in Wellington, New Zealand, for which we are most grateful. The views expressed in this paper are the authors and not those of the agencies with which they are affiliated or funded.

\section{References}

[1] Halder, P. (2014) Forest Biomass for Energy Production: Perceptions of State Forestry Professionals from China and India. Challenges, 5, 338-350. http://dx.doi.org/10.3390/challe5020338

[2] MacCormic, K. and Kautto, N. (2013) The Bioeconomy in Europe: An Overview. Sustainability, 5, 2589-2608. http://dx.doi.org/10.3390/su5062589

[3] Smith P., Bustamante, M., Ahammad, H., Clark, H., Dong, H., Elsiddig, E.A., Haberl, H., Harper, R., House, J., Jafari, M., Masera, O., Mbow, C., Ravindranath, N.H., Rice, C.W., Robledo Abad, C., Romanovskaya, A., Sperling, F. and 
Tubiello, F. (2014) Agriculture, Forestry and Other Land Use (AFOLU). In: Edenhofer, O., Pichs-Madruga, R., Sokona, Y., Farahani, E., Kadner, S., Seyboth, K., Adler, A., Baum, I., Brunner, S., Eickemeier, P., Kriemann, B., Savolainen, J., Schlömer, S., von Stechow, C., Zwickel, T. and Minx, J.C., Eds., Climate Change 2014: Mitigation of Climate Change. Contribution of Working Group III to the Fifth Assessment Report of the Intergovernmental Panel on Climate Change, Cambridge University Press, Cambridge, 811-922.

[4] Cherubini, F., Bird, N.D., Cowie, A., Jungmeier, G., Schlamadinger, B. and Gallasch, S.W. (2009) Energy- and Greenhouse Gas-Based LCA of Biofuel and Bioenergy Systems: Key Issues, Ranges and Recommendations. Resources, Conservation and Recycling, 53, 434-447. http://dx.doi.org/10.1016/j.resconrec.2009.03.013

[5] Cherubini, F. and Stromman, A.H. (2011) Life Cycle Assessment of Bioenergy Systems: State of the Art and Future Challenges. Bioresource Technology, 102, 437-451. http://dx.doi.org/10.1016/j.biortech.2010.08.010

[6] Havlík, P., Schneider, U.A., Schmid, E., Böttcher, H., Fritz, S., Skalský, R., Aoki, K., Cara, S.D., Kindermann, G., Kraxner, F., Leduc, S., McCallum, I., Mosnier, A., Sauer, T. and Obersteiner, M. (2011) Global Land-use Implications of First and Second Generation Biofuel Targets. Energy Policy, 39, 5690-5702. http://dx.doi.org/10.1016/j.enpol.2010.03.030

[7] Deppermann, A., Blesl, M., Boysen, O., Grethe, H. and Bruchof, D. Linkages between the Energy and Agricultural Sectors: Insights from European Union Greenhouse Gas Mitigation Scenarios. Mitigation and Adaptation Strategies for Global Change. (In Press)

[8] Forestry Agency of Japan (2013) Annual Report on Forest and Forestry in Japan: Fiscal Year 2012 (Summary). http://www.rinya.maff.go.jp/j/kikaku/hakusyo/24hakusyo/pdf/h24summary.pdf

[9] Yoshioka, T., Sakukrai, R., Aruga, K., Sakai, H., Kobayashi, H. and Inoue, K. (2011) A GIS-Based Analysis on the Relationship between the Annual Available Amount and the Procurement Cost of Forest Biomass in a Mountainous Region in Japan. Biomass and Bioenergy, 35, 4530-4537. http://dx.doi.org/10.1016/j.biombioe.2011.03.029

[10] Kamimura, K., Kuboyama, H. and Yamamoto, K. (2012) Wood Biomass Supply Cost and Potential for Biomass Energy Plants in Japan. Biomass and Bioenergy, 36, 107-115. http://dx.doi.org/10.1016/j.biombioe.2011.10.020

[11] Kamimura, K., Kuboyama, H. and Yamamoto, K. (2009) Estimation of Spatial Distribution on Wood Biomass Supply Potential for Three Prefectures in the Northern Tohoku Region. Journal of the Japan Institute of Energy, 88, 877-883. http://dx.doi.org/10.3775/jie.88.877

[12] Morimoto, H., Hashimoto, S., Hoshino, S. and Kuki, Y. (2010) Evaluation for Utilization of Woody Biomass in LargeScale, Centering on a Biomass Town: Case Study of Shiso City and Neighboring Districts, Hyogo prefecture. Journal of Rural Plannning Association, 29, 191-196. http://dx.doi.org/10.2750/arp.29.191

[13] Nakamura, R., Nakazawa, J. and Matsumoto, A. (2012) Regional Economic Effects of $\mathrm{CO}_{2}$ Reduction Activities with Wood Biomass: Application and Extension of a Regional IO Model. Studies in Regional Science, 42, 799-817. http://dx.doi.org/10.2457/srs.42.799

[14] Samuta, H., Uchiyama, Y. and Okajima, K. (2011) An Optimization Analysis of Bioenergy Production and Transportation in Ibaraki Prefecture. Journal of Japan Society of Energy and Resources, 32, 16-23.

[15] Kunii, D., Sawauchi, D. and Hayashi, T. (in press) Multi-dimensional Assessment of Environment and Economy based on Supply and Demand Matching of Woody Biomass: A Case Study of Firewood Use in Households in Nishiwaga. Studies in Regional Science.

[16] Tabata, T. and Okuda, T. (2012) Life Cycle Assessment of Woody Biomass Energy Utilization: Case Study in Gifu Prefecture, Japan. Energy, 45, 944-951. http://dx.doi.org/10.1016/j.energy.2012.06.064

[17] Executive Office of Energy and Environmental Affairs (2008) Woody Biomass Energy: Local Renewable Fuel for Commercial, Institutional and Industrial Facilities. http://www.mass.gov/eea/docs/doer/renewables/biomass/woody-biomass-energy.pdf

[18] Nishiwaga-machi (2011) Proposal to Form a System to Optimize the Use of "Firewood". http://www.town.nishiwaga.lg.jp/index.cfm/8,10397,c,html/10397/20110426-181119.pdf

[19] Japan Petroleum Energy Center (2000) Report on LCI of Petroleum Products and Environmental Impact Assessment of Petroleum Products.

[20] Kumazaki, M. (2000) Expectations of Wood Biomass Power Generation. National Forestry Improvement Promotion Association, Tokyo, Japan.

[21] Ministry of the Environment (2005) Guidelines for a Method to Calculate the Greenhouse Gas Emissions from Business Operators. http://www.env.go.jp/earth/ondanka/santeiho/guide/index.html

[22] Agency for Natural Resources and Energy (2006) Guidelines for Creating Energy Consumption Statistics by Municipality. http://www.kanto.meti.go.jp/seisaku/ondanka/pdf/060608shiryo1-4.pdf 